\title{
Pengaruh Hasil Investasi, Pendapatan Premi, dan Beban Klaim Terhadap Pertumbuhan Aset pada Asuransi Jiwa Yang Terdaftar di Otoritas Jasa Keuangan (OJK) Periode Tahun 2014-2017
}

\author{
Akuntansi Keuangan \\ Erlin Nur Setiobekti ${ }^{1}$, Tabrani ${ }^{2}$, Subekti ${ }^{{ }^{*}}$ \\ Fakultas Ekonomi dan Bisnis, Universitas Pancasakti Tegal \\ Email: subekti.ups@gmail.com
}

\begin{abstract}
The purpose of this research was to analyze the effect of investment returns, premium income and claims for the growth of assets life insurance at the Financial Services Authority. The population in this research are life insurance companies on the Financial Services Authority at period 2014-2017. The analyze technique used is multiple linier regression.The results of calculations with the $F$ test of 7.168 with growth of assets 0.000 means that simultan investment returns, premium income and claims affect the growth of assets. The results of calculations with the t test of the coefficient of investment returns of -3,294 with a significance level of 0.001 smaller than 0.05 then there is the effect of investment returns on the growth of assets, the value of the premium income coefficient of 4,564 with a significance level of 0,000 less than 0.05 then there is an influence of premium income on the growth of assets, and the claims coefficient value of -3,617 with a significance level of 0,000 less than 0.05, there is an influence of the claims on the growth of assets.
\end{abstract}

Keywords: Investment Return, Premium Income, Claims, Growth of assets

\begin{abstract}
Abstrak
Penelitian ini bertujuan untuk menguji pengaruh hasil investasi, pendapatan premi dan beban klaim terhadap pertumbuhan aset pada asuransi jiwa yang terdaftar di Otoritas Jasa Keuangan. Populasi dalam penelitian ini adalah seluruh perusahaan asuransi jiwa yang terdaftar di Otoritas Jasa Keuangan periode 2014-2017. Metode yang digunakan dalam penelitian ini adalah kuantitatif dengan data sekunder melalui situs resmi Otoritas Jasa Keuanagn. Alat analisis yang digunakan dalam penelitian ini yaitu analisis regresi linear berganda. Hasil perhitungan dengan uji $\mathrm{F}$ sebesar 7.168 dengan pertumbuhan aset 0.000 berarti secara simultan hasil investasi, pendapatan premi dan beban klaim berpengaruh terhadap pertumbuhan aset. Hasil perhitungan dengan uji t nilai koefisien hasil investasi sebesar -3.294 dengan tingkat signifikasinya 0.001 lebih kecil dari 0.05 maka terdapat pengaruh hasil investasi terhadap pertumbuhan aset, nilai koefisien pendapatan premi sebesar 4.564 dengan tingkat signifikasinya 0.000 lebih kecil dari 0.05 maka terdapat pengaruh pendapatan premi terhadap pertumbuhan aset, dan nilai koefisien beban klaim sebesar -3.617 dengan tingkat signifikasinya 0.000 lebih kecil dari 0.05 maka terdapat pengaruh beban klaim terhadap pertumbuhan aset.
\end{abstract}

Kata kunci : Hasil Investasi, Pendapatan Premi, Beban Klaim, Pertumbuhan Aset. 


\section{Pendahuluan}

Di Indonesia banyak berdiri asuransi-asuransi yang dengan tujuan masingmasing didirikannya perusahaan asuransi tersebut. Menurut UU No.2 Tahun 1992 Pasal 1 menyatakan bahwa Asuransi atau Pertanggungan adalah perjanjian antara dua pihak atau lebih, dimana pihak penanggung mengikatkan diri dengan pihak tertanggung, dengan menerima premi asuransi, untuk memberikan pergantian kepada tertanggung karena kerugian, kerusakan atau kehilangan keuntungan yang diharapkan, atau tanggung jawab hukum kepada pihak ketiga yang mungkin diderita tertanggung yang timbul dari suatu peristiwa yang tidak pasti, atau untuk pembayaran yang didasarkan atas meninggal atau hidupnya orang yang dipertanggungkan. Dengan kata lain pihak tertanggung memiliki motif untuk berjaga-jaga dimasa yang akan datang atau telah mengantisipasi dirinya sendiri apabila terjadi hal-hal yang tidak terduga atau yang tidak diinginkan.

Semua orang sebenarnya menyadari bahwa hidup penuh dengan ketidakpastian kecuali kematian, yang sebenarnya bahwa kematian juga tetap mengandung ketidakpastian di dalamnya, orang tidak tahu pasti mengenai kapan waktu dan penyebab apa kematian itu terjadi. Ketidakpastian tersebut yang mengakibatkan adanya risiko bagi pihak-pihak yang berkepentingan. Anggapan setiap orang terhadap kata "Risiko" selalu dibayang - bayangi dengan kata yang berkonotasi negatif. Padahal dalam kehidupan sehari-hari, setiap orang dituntut untuk menghadapi suatu risiko baik itu kecil maupun besar. Contoh kecil, ketika seseorang sedang asyik menikmati kopi panasnya maka berisiko untuk terkena tumpahannya, dan ketika seseorang sedang mengendarai kendaraannya di sebuah jalan maka berisiko untuk mengalami sebuah kecelakaan. Banyak contoh lain yang menegaskan bahwa hidup kita sangat dekat dengan risiko (Yulia Tedjo, 2016)

Namun, sebenarnya risiko tak selalu bermakna negatif. Risiko juga memiliki sisi baik yaitu dapat memacu kehidupan seseorang untuk menjadi lebih baik sehingga tak hanya monoton dari waktu ke waktu sehingga berupaya untuk berupaya meningkatkan kualitas diri. Oleh karena itu, suatu risiko perlu dikenali dengan baik agar dapat dikelola secara tepat. Asuransi pada hakikatnya adalah suatu sistem proteksi menghadapi resiko kerugian financial dengan cara pengalihan (transfer) risiko kepada pihak lain baik secara perorangan maupun secara berkelompik dalam masyarakat. Usaha asuransi mempunyai sifat dan karakteristik yang berbeda dengan jenis usaha dibidang jasa pada umumnya karena usaha asuransi mengambil berbagai risiko dari pihak lain sehingga asuransi menjadi padat risiko bila tidak dikeloladengan baik. Dasar usaha asuransi adalah kepercayaan masyarakat, terutama dalam hal kemampuan keuangan (bonafiditas) perusahaan untuk memenuhi kewajiban sebuah klaim dan kewajiban lain-lain tepat pada waktunya. Untuk itu usaha asuransi harus dikelola secara profesional, baik dalam pengelolaan risiko maupun pengelolaan keuangan (siti Hadijah, 2017)

Asuransi termasuk bisnis yang diatur secara ketat oleh pemerintah dengan tujuan untuk melindungi konsumen dari kemungkinan terjadinya kecurangan 
perusahaan. Pemerintah mengatur adanya batas rasio dari permodalan terhadap premi terkumpul atau yang telah terakumulasi yang telah menyebabkan beberapa perusahaan masuk dalam kategori insolvent (bangkrut). Oleh karenanya sangat penting bagi perusahaan asuransi untuk dapat mengukur dan membandingkan kinerja perusahaan mereka dengan efektif dan efisien agar dapat bertahan dan bersaing dalam dunia bisnis.

Perusahaan asuransi senantiasa mengevaluasi kegiatan operasional perusahaan mereka sepanjang tahun, dengan mengidentifikasi berbagai macam faktor internal maupun faktor eksternal yang dimana dapat mempengaruhi solvabilitas dan profitabilitas bisnis perusahaan. Apa dan bagaimana yang harus dilakukan perusahaan dalam menghadapi karakteristik pasar sekarang dan masa yang akan datang, serta perusahaan harus mampu memprediksi dalam menilai industri asuransi secara umum. Ketika perusahaan dapat memprediksi penilaian industri asuransi selanjutnya adalah bagaimana perusahaan yang harus dapat menyediakan informasi tentang sejauh mana suatu kegiatan telah tercapai, bagaimana perbedaan pencapaian itu dengan suatu standar tertentu yang menjadi dasar untuk mengetahui apakah ada selisih diantara keduanya, serta bagaimana manfaat yang telah dikerjakan itu bila dibandingkan dengan harapan-harapan yang ingin diperoleh (Fifi Afiyati, 2012)

Menurut otoritas jasa keuangan (OJK) jumlah perusahaan asuransi di Indonesia ada 137 perusahaan, dimana dalam jumlah tersebut untuk perusahaan asuransi umum berjumlah 76 perusahaan, Asuransi jiwa berjumlah 50 perusahaan, asuransi reasuransi ada 6 perusahaan, asuransi wajib ada 3 perusahaan dan asuransi sosial terdapat 2 perusahaan. Sedangkan untuk perusahaan asuransi syariah ada sebanyak 50 perusahaan, dimana terdapat 23 perusahaan asuransi jiwa syariah, 25 perusahaan asuransi umum syariah, dan 2 perusahaan reasuransi syariah.

Aset bagi Perusahaan Asuransi Jiwa sangatlah penting baik untuk memenuhi kewajiban jangka panjang maupun jnagka pendek. Pengelolaan aset suatu perusahaan asuransi jiwa harus dilakukan secara hati-hati dan jeli karena mengingat risiko yang nantinya akan dihadapi oleh perusahaan asuransi jiwa itu sendiri. Aset dan kewajiban harus sesuai karena kontrak asuransi adalah jangka panjang dimana yang seperti kita ketahui beberapa aset mungkin telah jatuh tempo dalam waktu jangka pendek sedangkan kewajiban (liabilities) merupakan kategori kewajiban jangka panjang (Istianingsih,2015).

Kesuksesan kebijakan investasi dalam sebuah perusahaan asuransi dapat menjadi penyebab dalam pengelolaan asset yang bagus. Hal demikian tersebut disebabkan karena perusahaan asuransi jiwa telah menahan premi dalam beberapa waktu sebelum membayarkan premi tersebut kepada tertanggung yang nantinya menjadi manfaat bagi perusahaan asuransi jiwa. Adanya kesempatan dalam pengelolaan yang seperti dijelaskan diatas maka akan sangat memungkinkan perusahaan asuransi untuk memperoleh return atau pengembalian hasil yang bagus sehingga dapat lebih kompetitif dan bagi pemegang polis dapat menerima manfaat keuntungan dari kegiatan perasuransian tersebut, hal tersebut juga menjadi pemicu mendapatkan bonus bagi manajer dan adanya kesempatan karir yang bagus bagi staf perusahaan. Namun disisi lain jika resiko investasinya menghasilkan kerugian, maka 
pihak penanggung biasanya harus menambah modal untuk melanjutkan kelangsungan bisnisnya supaya tetap beroperasi, penambahan modal yang dilakukan oleh perusahaan asuransi biasanya dalam jumlah yang besar dan diharapkan dapat memperbaiki keadaan perusahaan yang jika terjadi kerugian. Oleh karena itu, kejelian dalam memprediksi kerjasama dalam perusahaan asuransi jiwa antar pihak tertanggung dan penanggung harus sangat diperhitungkan.

Fenomena yang terjadi pada perusahaan asuransi jiwa saat ini mengenai pertumbuhan asset yang cenderung naik turun. Otoritas Jasa Keuangan mencatat sepanjang tahun 2015 aset industri asuransi jiwa hanya tumbuh $2 \%$, pertumbuhan tersebut adalah yang terendah dalam 5 tahun terakahir. Dimana sebelumnya sejak 2010 hingga 2014 rata-rata pertumbuhan aset asuransi jiwa adalah sebesar 18\%. Dalam rentang waktu tersebut pertumbuhan tertinggi terjadi pada tahun 2014 yang mencapai 25\% dan terendah pada tahunn 2013 dimana aset hanya naik 9\% saja (www.Jiwasraya.com, 2016).

Berdasarkan berita yang dimuat di media masa oleh syike febrina menyatakan bahwa jumlah investasi di kuartal IV 2017, untuk perusahaan asuransi jiwa mengalami peningkatan 22,8\% menjadi Rp 486,2 triliun dari periode sebelumnya Rp 395,96 triliun. kenaikan di sejumlah indikator tersebut turut mempengaruhi pertumbuhan total aset sebesar 24,6\% atau menjadi Rp 542,61 triliun dibandingkan dengan periode yang sama tahun 2016 yakni Rp 435,53 triliun (www.detik.com, 2018). Hal ini membuktikan pernyataan sebelumnya tentang penyebab pertumbuhan asset adalah dari investasinya yang bagus.

Mutia fauzia menyatakan tentang asuransi jiwa pada kuartal I/2018 menyatakan bahwa total pendapatan dari industri asuransi jiwa di kuartal pertama tahun 2018 mengalami perlambatan, hal ini disebabkan adanya nilai negatif dari hasil investasi di kuartal I/2018. Sementara untuk total pendapatan premi merupakan kontributor terbanyak atas total pendapatan industri asuransi jiwa, yaitu sebesar 10,1 persen. Total pendapatan premi tercatat masih tumbuh kearah yang baik yakni 23,3 persen, menjadi Rp 52,49 triliun pada kuartal I/2018. Pertumbuhan dari total pendapatan premi tersebut disebabkan oleh meningkatnya premi dari berbagai saluran distribusi bancassurance. Pendapatan dari jalur ini meningkat menjadi 41,1 persen dan berkontribusi sebesar 46,4 persen terhadap pertumbuhan premi. Selain hasil investasi tentunya hal ini juga berdampak terhadap pertumbuhan total aset asuransi jiwa di Indonesia (https://www.kompas.com, 2018).

Adapun penelitian ini mengacu penelitian Muhammad Ikhsan, dkk (2015), yaitu memiliki variabel dependen dan dua variabel independen yang sama yaitu premi dan klaim, namun perbedaannya dalam penelitian Muhammad Ikhsan, dkk (2015) hanya menggunakan dua variabel independen yaitu premi dan klaim sedangkan dalam penelitian ini memiliki tiga variabel yaitu hasil investasi, pendapatan premi, dan beban klaim

Demikian pula yang dilakukan oleh perusahaan Asuransi jiwa yang merupakan salah satu perusahaan yang ada di Indonesia, Berdasarkan latar belakang masalah yang telah dikemukakan, maka penulis mengambil judul penelitian tentang "Pengaruh Hasil 
Investasi, Pendapatan Premi dan Beban Klaim Terhadap Pertumbuhan Aset Pada Asuransi Jiwa yang Terdaftar di Otoritas Jasa Keuangan (OJK) Periode Tahun 20142017'. Berdasarkan latar belakang tersebut, perumusan suatu masalah harus jelas, dan sesuai dengan data-data atau informasi yang diperoleh. Adapun perumusan masalah yang peneliti kemukakan adalah sebagai berikut: Apakah terdapat pengaruh hasil investasi secara parsial terhadap pertumbuhan asset pada asuransi jiwa yang terdaftar di Otoritas Jasa Keuangan?, Apakah terdapat pengaruh pendapatan premi secara parsial terhadap pertumbuhan asset pada asuransi jiwa yang terdaftar di Otoritas Jasa Keuangan?, Apakah terdapat pengaruh beban klaim secara parsial terhadap pertumbuhan asset pada asuransi jiwa yang terdaftar di Otoritas Jasa Keuangan? Rumusan Masalah tersebut bertujuan untuk mengetahui pengaruh hasil investasi secara parsial terhadap pertumbuhan asset pada asuransi jiwa yang terdaftar di Otoritas Jasa Keuangan, untuk mengetahui pengaruh pendapatan premi secara parsial terhadap pertumbuhan asset pada asuransi jiwa yang terdaftar di Otoritas Jasa Keuangan, dan untuk mengetahui pengaruh beban klaim secara parsial terhadap pertumbuhan asset pada asuransi jiwa yang terdaftar di Otoritas Jasa Keuangan Periode Tahun 2014-2017.

\section{Kerangka Pemikiran dan Hipotesis}

\subsection{Pengaruh Hasil Investasi Terhadap Pertumbuhan Aset}

Pengaruh hasil investasi terhadap pertumbuhan asset. Investasi adalah penanaman modal untuk satu atau lebih aktiva yang dimiliki dan biasanya berjangka waktu lama dengan harapan mendapatkan keuntungan di masa-masa yang akan datang (Sunariyah, 2004:4). Investasi terdapat hubungan yang searah antara pendapatan dan pertumbuhan aset, dimana semakin besar pendapatan premi yang didapat perusahaan asuransi mkan semakin besar pula dana yang dapat diinvestasikan sehingga nantinya akan diperoleh hasil investasi yang besar. Hal ini juga berpengaruh terhadap besar kecilnya pertumbuhan aset.

H1. Diduga terdapat pengaruh hasil investasi terhadap pertumbuhan aset pada asuransi jiwa yang terdaftar di Otoritas Jasa Keuangan (OJK) periode tahun 20142017.

\subsection{Pengaruh pendapatan premi terhadap pertumbuhan aset}

Premi merupakan pembayaran sejumlah uang yang dilakukan oleh pihak tertanggung kepada penaggung untuk mengganti suatu kerugian, kerusakan atau kehilangan keuntungan yang diharapakan akibat timbulnya perjanjian atas pemindahan resiko dari tertanggung kepada penanggung (Amrin, 2006: 108). Meskipun nilai hasil investasi besar belum tentu akan mendapatkan premi yang besar pula, hal ini disebabkan karena adanya klaim dalam asuransi yang dapat mempengaruhi besarnya premi. Premi yang baik dapat meningkatkan efisiensi biaya perusahaan. Hal ini sesuai dengan teori biaya yang menyatakan bahwa semakin tinggi produksi maka biaya rata-rata perproduk makin lama makin rendah sehingga akan makin dapat bersaing di pasar. 
H2. Diduga terdapat pengaruh pendapatan premi terhadap pertumbuhan aset pada asuransi jiwa yang terdaftar di Otoritas Jasa Keuangan (OJK) periode tahun 20142017.

\subsection{Pengaruh beban klaim terhadap pertumbuhan aset.}

Klaim merupakan kegiatan yang menyangkut penyelidikan, penilaian, dan penyelesaian tuntutan ganti rugi yang diajukan oleh tertanggung (Danang Sunyoto, 2017:112). Sehingga klaim merupakan beban yang harus ditanggung oleh perusahaan asuransi. Setiap terjadinya klaim akan mengurangi pertumbuhan asset asuransi. Dengan kata lain setiap ada kenaikan klaim maka akan mengurangi asset pada perusahaan asuransi. Besarnya beban klaim yang diterima maka akan berdampak pula pada asset perusahaan asuransi. Beban mewakilkan kenaikan kewajiban atau penurunan asset, dengan efek berikutya pada ekuitas, Jadi dapat disimpulkan terdapat hubunngan terbalik antara beban dan pertumbuhan asset, yaitu jika ada kenaikan dari beban maka ada penurunan untuk asset. Oleh karena itu, jika terjadi klaim maka dapat mengurangi pertumbuhan asset.

H3. Diduga terdapat pengaruh beban klaim terhadap pertumbuhan aset asuransi yang terdaftar di Otoritas Jasa Keuangan (OJK) periode tahun 2014-2017.

\section{Metode Penelitian}

\subsection{Jenis dan Pendekatan Penelitian}

Pemilihan metode dalam penelitian ini adalah dengan penelitian kuantitatif merupakan salah satu jenis penelitian yang berdasarkan pada filsafat positivisme, yang dapat digunakan untuk meneliti populasi atau sampel tertentu, pengumpulan data menggunakan instrument penelitian, analisis data bersifat kuantitatif atau statistik, dengan tujuan untuk menguji hipotesis yang telah ditetapkan. Objek Penelitian ini adalah pada perusahaan asuransi jiwa yang terdaftar dalam pengawas lembaga keuangan yaitu Otoritas Jasa Keuangan (OJK) dari tahun 2014 - 2017. Populasi dari penelitian ini yaitu perusahaan asuransi jiwa yang tercatat dalam Otoritas Jasa Keuangan yang berjumlah sebanyak 50 perusahaan asuransi jiwa. Dengan menggunakan rumus slovin maka didapatkan jumlah perusahaan dalam penelitian sebanyak 33 perusahaan asuransi jiwa.

\subsection{Definisi Konseptual dan Operasional Variabel}

\section{Definisi konseptual}

a. Pertumbuhan Aset

Asset merupakan aktiva yang digunakan untuk aktivitas operasional perusahaan. Semakin besar asset diharapkan semakin besar hasil operasional yang dihasilkan oleh perusahaan. Pertumbuhan asset didefinisikan sebagai perubahan tahunan dari total aktiva. Peningkatan asset yang diikuti peningkatan hasil operasi akan semakin menambah kepercayaan pihak luar terhadap perusahaan(Martono dan Harjito, 2013: 133). 
b. Hasil Investasi

Investasi adalah penanaman modal untuk satu atau lebih aktiva yang dimiliki dan biasanya berjangka waktu lama dengan harapan mendapatkan keuntungan di masa-masa yang akan datang (Sunariyah, 2004;4)

c. Pendapatan Premi

Pengertian Premi merupakan pembayaran sejumlah uang yang dilakukan oleh pihak tertanggung kepada penaggung untuk mengganti suatu kerugian, kerusakan atau kehilangan keuntungan yang diharapakan akibat timbulnya perjanjian atas pemindahan resiko dari tertanggung kepada penanggung (Amrin, 2006;108).

d. Beban Klaim

Klaim merupakan kegiatan yang menyangkut penyelidikan, penilaian, dan penyelesaian tuntutan ganti rugi yang diajukan oleh tertanggung (Danang Sunyoto, 2017:112)

\section{Definisi Operasional Variabel.}

Definisi Operasional Variabel menjelaskan mengenai variabel - variabel yang digunakan dalam penelitian.

Tabel 3.2

Definisi Operasional Variabel

\begin{tabular}{|l|l|l|}
\hline Variabel & Indikator & Skala \\
\hline $\begin{array}{l}\text { Pertumbuhan Aset } \\
\text { Putri Amanda, 2017) }\end{array}$ & $\begin{array}{l}\text { Persentase perubahan (peningkatan atau } \\
\text { penurunan) Pertumbuhan Aset = }\end{array}$ & Rasio \\
& $\begin{array}{l}\text { Total asset t - total asset t-1 x 100\% } \\
\text { Total asset t-1 }\end{array}$ & \\
\hline $\begin{array}{l}\text { Hasil Investasi (Putri } \\
\text { Amanda, 2017) }\end{array}$ & $\begin{array}{l}\text { Total Hasil Investasi dari nilai hasil } \\
\text { Investasi }\end{array}$ & Rasio \\
\hline $\begin{array}{l}\text { Pendapatan Premi } \\
\text { (Putri Amanda, 2017) }\end{array}$ & $\begin{array}{l}\text { Total Pendapatan Premi dari pendapatan } \\
\text { Premi. }\end{array}$ & Rasio \\
\hline $\begin{array}{l}\text { Beban Klaim } \\
\text { (Putri Amanda, 2017) }\end{array}$ & Total Beban Klaim dari Beban Klaim. & Rasio \\
\hline
\end{tabular}

Sumber : Operasional Tabel

\subsection{Analisis Data dan Uji Analisis}

Metode analisis data yang digunakan yaitu dengan menggunakan analisis regresi berganda. Sedangkan uji analisis menggunakan analisis Deskriptif, Uji asumsi klasik, Uji Koefisien Regresi Parsial (Uji t) dan Uji Koefisien Regresi Simultan (Uji F), serta menyertakan Koefisien diterminasi $\left(\mathrm{R}^{2}\right)$. 


\section{Hasil}

\subsection{Uji Statistik Deskriptif}

Statistik deskriptif dalam penelitian ini digunakan untuk memberikan informasi mengenai variabel-variabel penelitian seperti Pertumbuhan asset (Y), hasil investasi $\left(\mathrm{X}_{1}\right)$, pendapatan premi $\left(\mathrm{X}_{2}\right)$ dan beban klaim $\left(\mathrm{X}_{3}\right)$. Hasil pengujian statistik deskriptif untuk variabel-variabel penelitian tersebut dapat dilihat pada tabel berikut.

Tabel 4.1

Hasil Uji Statistik Deskriptif

Descriptive Statistics

\begin{tabular}{|l|r|r|r|r|r|}
\hline & $\mathrm{N}$ & Minimum & $\begin{array}{c}\text { Maximu } \\
\mathrm{m}\end{array}$ & Mean & Std. Deviation \\
\hline Ln_Y & 132 & -4.83 & .32 & -1.8357 & 1.18757 \\
Ln_x1 & 132 & 7.31 & 16.22 & 12.402 & 1.87605 \\
Ln_x2 & 132 & 9.35 & 17.11 & 14.090 & 1.69412 \\
Ln_x3 & 132 & 7.73 & 16.57 & 13.220 & 1.86732 \\
Valid N & 132 & & & 9 & \\
(listwise) & & & & & \\
\hline
\end{tabular}

Sumber: Data Sekunder yang diolah, 2018

Berdasarkan tabel 4.1 dapat diketahui bahwa terdapat 132 sampel dari masingmasing variabel yang diteliti. Pertumbuhan asset yaitu variabel Y memiliki rata-rata 1.8357 dengan nilai tertinggi 0.32 dan nilai terendah -4.83 . Sedangkan standar deviasinya sebesar 1.18757, yang artinya selama periode penelitian ukuran penyebaran dari variabel pertumbuhan asset asuransi yaitu sebesar 1,187\%.

Untuk hasil investasi diperoleh rata-rata 12.4026 dengan nilai tertinggi 16.22 oleh dan nilai terendah 7.31. Sedangkan standar deviasinya sebesar 1.87605, yang artinya selama periode penelitian ukuran penyebaran dari variabel hasil investasi yaitu sebesar $1.876 \%$.

Untuk pendapatan premi diperoleh rata-rata 14.0909 dengan nilai tertinggi 17.11 oleh dan nilai terendah 9.35. Sedangkan standar deviasinya sebesar 1.69412, yang artinya selama periode penelitian ukuran penyebaran dari variabel pendapatan premi yaitu sebesar $1.694 \%$.

Untuk beban klaim diperoleh rata- rata 13.2209 dengan nilai tertinggi 16.57 dan nilai terendah 7.73. Sedangkan standar deviasinya sebesar 1.86732, yang artinya selama periode penelitian ukuran penyebaran dari variabel beban klaim yaitu sebesar $1.867 \%$.

\section{Uji Asumsi Klasik}

\section{a. Uji Normalitas}


Untuk menguji normalitas ada dua cara, yaitu grafik histogram dan normal probability plots. Hasil uji normalitas secara grafik histogram dan normal probability plots dengan menggunakan SPSS versi 23 ditunjukkan dengan grafik di bawah ini.

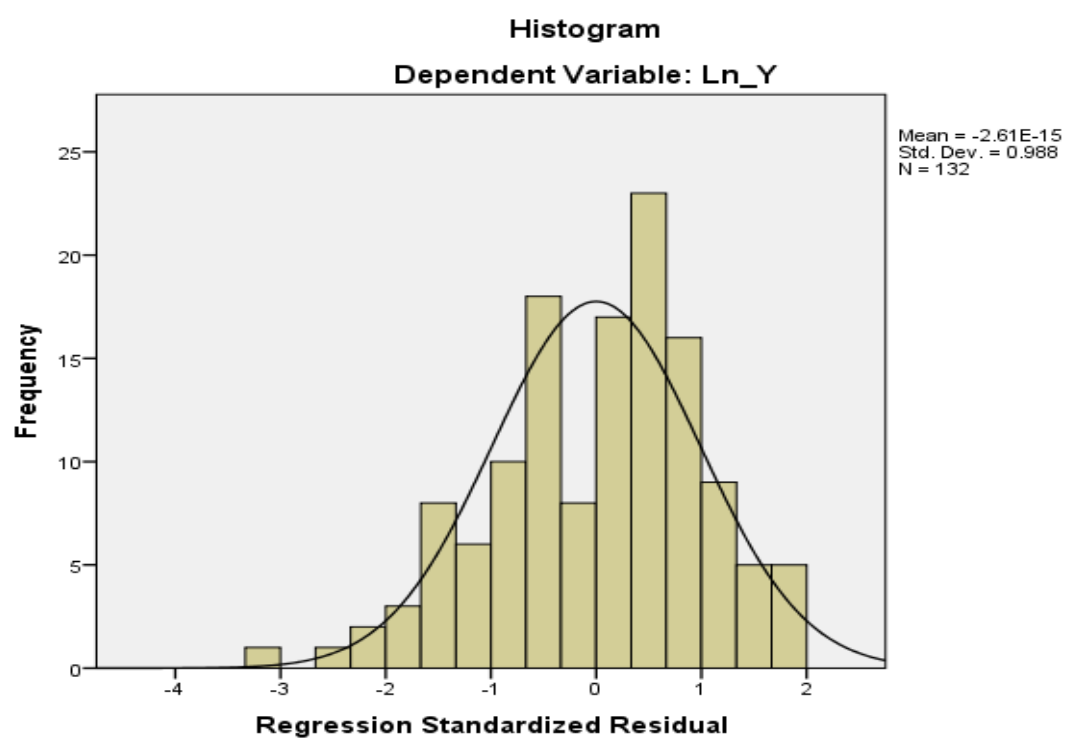

Sumber: Data Sekunder yang diolah, 2018

Gambar 4.2

Hasil Uji Normalitas dengan Grafik Histogtram

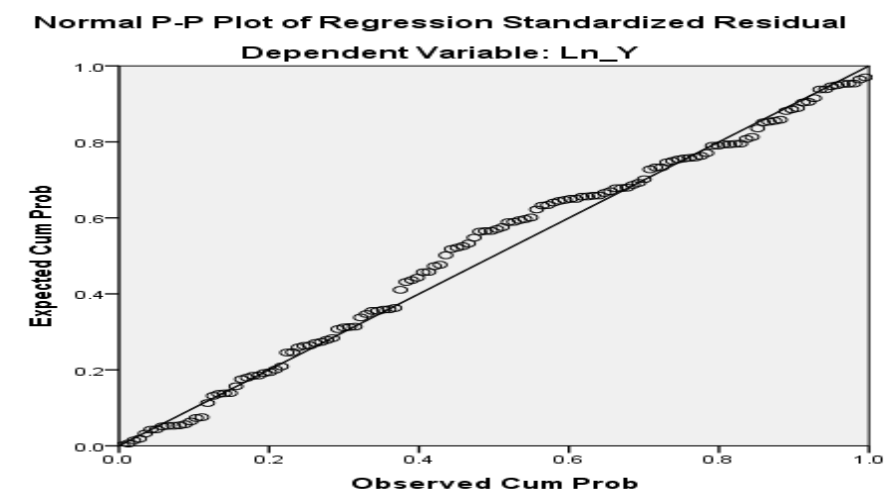

Sumber: Data Sekunder yang diolah, 2018

Gambar 4.3

Hasil Uji Normalitas dengan Normal Probability Plots

Dari grafik histogram maupun normal probability plots dapat disimpulkan bahwa grafik histrogram tidak memberikan pola distribusi menceng (skewness). Sedangkan pada grafik normal probability plots terlihat bahwa titik-titik dari data penelitian menyebar di sepanjang sekitar garis diagonal dan mengikuti garis diagonal atau grafik histogramnya. Dengan demikian, melihat dari kedua hasil uji tersebut maka dapat dinyatakan bahwa penyebaran data mendekati normal atau memenuhi asumsi normalitas. 
b. Uji Multikolinearitas

Tabel 4.2

Hasil Uji Multikolinearitas

Coefficients $^{\mathrm{a}}$

\begin{tabular}{|l|r|r|}
\hline \multirow{2}{*}{ Model } & \multicolumn{2}{|c|}{ Collinearity Statistics } \\
\cline { 2 - 3 } & \multicolumn{1}{|c|}{ Tolerance } & \multicolumn{2}{|c|}{ VIF } \\
\hline (Constant) & .297 & 3.372 \\
Ln_x1 & .132 & 7.562 \\
Ln_x2 & .229 & 4.362 \\
Ln_x3 & & \\
\hline
\end{tabular}

Sumber : Data Sekunder yang diolah, 2018

Berdasarkan hasil uji multikolinearitas di atas menunjukkan bahwa untuk semua variabel independen yaitu hasil investasi, pendapatan premi dan beban klaim masing-masing memiliki angka tolerance di atas 0.1 dan angka VIF kurang dari 10 sehingga data yang digunakan tidak melebihi batas nilai VIF yang diperkenankan yaitu sebesar 10. Dari hasil diatas maka dapat dinyatakan bahwa dalam model regresi tidak terjadi masalah multikolinearitas.

c. Uji Autokorelasi

Tabel 4.3

Hasil Uji Autokorelasi

Model Summary

\begin{tabular}{|l|l|}
\hline Model & \multicolumn{2}{|c|}{ Durbin-Watson } \\
\hline 1 & \\
\hline
\end{tabular}

Sumber : Data sekunder yang diolah, 2018

Dari hasil olah data menggunakan SPSS menunjukkan bahwa nilai Durbin Watson sebesar 1.841, nilai tersebut lebih besar dari -2 dan lebih kecil dari +2 atau $-2<1.051<+2$. Maka dapat disimpulkan bahwa data yang dipakai tersebut tidak terjadi autokorelasi. 


\section{d. Uji Heteroskesdastisitas}

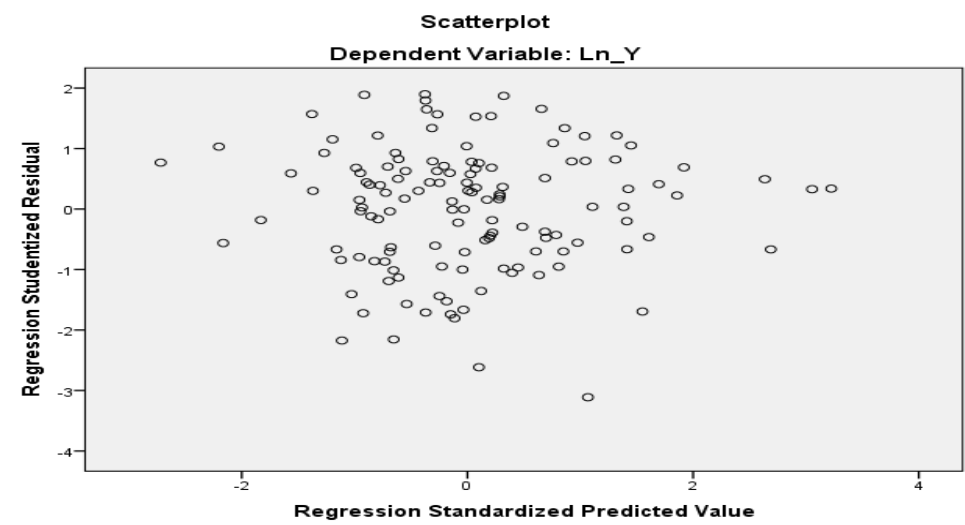

Sumber : Data Sekunder yang diolah, 2018

Gambar 4.4

Hasil Uji Heteroskesdastisitas

Berdasarkan grafik 4.4 menunjukkan bahwa tidak ditemukan adanya pola tertentu yang teratur dan titik-titik menyebar di atas maupun dibawah angka 0 pada sumbu Y. Hal ini berarti membuktikan bahwa tidak terjadi heterokesdastisitas pada model regresi.

\section{Analisis Regresi Linear Berganda}

Tabel 4.4

Hasil Uji Analisis Regresi Linear Berganda

Coefficients

\begin{tabular}{|c|c|c|c|}
\hline \multirow{2}{*}{\multicolumn{2}{|c|}{ Model }} & \multicolumn{2}{|c|}{ Unstandardized Coefficients } \\
\hline & & $\mathrm{B}$ & Std. Error \\
\hline \multirow[t]{4}{*}{$\overline{1}$} & (Constant) & -1.733 & .834 \\
\hline & Ln_x1 & .009 & .000 \\
\hline & Ln_x2 & .392 & .000 \\
\hline & Ln_x3 & -.434 & .000 \\
\hline
\end{tabular}

Sumber : Data Sekunder yang diolah, 2018

Hasil analisis regresi berganda diperoleh koefisien untuk variabel independen $\mathrm{X} 1=0.009, \mathrm{X} 2=0.392$ dan $\mathrm{X} 3=-0.434$ dengan konstanta sebesar 0.130 . sehingga diperoleh model persamaan regresi:

$\mathrm{Y}=-1,733+0,009 \mathrm{Ln} \_\mathrm{x} 1+0.392 \mathrm{Ln} \_\mathrm{x} 2-0.434 \mathrm{Ln} \_\mathrm{x} 3$

Berdasarkan model regresi pada tabel 4.4 maka dapat dijelaskan :

a. Konstanta sebesar -1,733 menyatakan bahwa variabel jika variabel independen diasumsikan konstan, maka variabel dependen akan turun sebesar 1,73\%.

b. Variabel hasil investasi dengan nilai koefisien regresi positif 0.009 menunjukkan bahwa pengaruh hasil investasi terhadap pertumbuhan aset adalah positif. Hal ini menggambarkan jika terjadi kenaikan hasil investasi sebanyak 
$1 \%$ akan menyebabkan pertumbuhan aset naik hanya sebesar $0.01 \%$ dengan asumsi variabel independen yang dianggap konstan.

c. Variabel pendapatan premi dengan nilai koefisien regresi positif 0.392 menunjukkan bahwa pengaruh pendapatan premi terhadap pertumbuhan aset adalah positif. Hal ini menggambarkan jika terjadi kenaikan bagi hasil sebanyak $1 \%$ maka pertumbuhan aset akan naik sebesar $0.39 \%$ dengan asumsi variabel independen yang dianggap konstan.

d. Variabel beban klaim dengan nilai koefisien regresi negatif -0.434 menunjukkan bahwa pengaruh beban klaim terhadap pertumbuhan aset adalah negatif. Hal ini menggambarkan jika terjadi kenaikan beban klaim sebanyak $1 \%$ akan menyebabkan pertumbuhan aset turun sebesar $0.43 \%$ dengan asumsi variabel independen yang dianggap konstan.

\section{Uji Hipotesis}

\section{Uji Statistik t (Parsial)}

Tabel 4.5

Hasil Uji Parsial

Coefficients $^{a}$

\begin{tabular}{|c|c|c|c|}
\hline \multicolumn{2}{|c|}{ Model } & $\mathrm{T}$ & Sig. \\
\hline 1 & (Constant) & 3.864 & .000 \\
\hline & Ln_x1 & -3.294 & .001 \\
\hline & Ln_x2 & 4.564 & .000 \\
\hline & Ln_x3 & -3.617 & .000 \\
\hline
\end{tabular}

Sumber : Data Sekunder yang diolah, 2018

Pada tabel 4.5 menunjukkan bahwa angka signifikasi untuk variabel hasil investasi yaitu 0.001. Untuk menentukan pengujian menggunakan tingkat signifikasi 5\% (0.05). Karena angka signifikasi variabel hasil investasi lebih kecil dari tingkat signifikasinya maka hipotesis yang menyatakan bahwa "terdapat pengaruh hasil investasi secara parsial terhadap pertumbuhan asset pada asuransi jiwa yang terdaftar di Otoritas Jasa Keuangan" diterima.

Pada tabel 4.5 menunjukkan bahwa angka signifikasi untuk variabel pendapatan premi yaitu 0.000. Untuk menentukan pengujian menggunakan tingkat signifikasi 5\% (0.05). Karena angka signifikasi variabel pendapatan premi lebih kecil dari tingkat signifikasinya maka hipotesis yang menyatakan bahwa "terdapat pengaruh pendapatan premi secara parsial terhadap pertumbuhan asset pada asuransi jiwa yang terdaftar di Otoritas Jasa Keuangan.” dapat diterima.

Pada tabel 4.5 menunjukkan bahwa angka signifikasi untuk variabel beban klaim yaitu 0.000. Untuk menentukan pengujian menggunakan tingkat signifikasi 5\% (0.05). Karena angka signifikasi variabel beban klaim lebih kecil dari tingkat signifikasinya maka hipotesis yang menyatakan bahwa "terdapat pengaruh beban 
klaim secara parsial terhadap pertumbuhan asset pada asuransi jiwa yang terdaftar di Otoritas Jasa Keuangan.” dapat diterima.

Uji Statistik F (Simultan)

Tabel 4.6

Hasil Uji Simultan

ANOVA $^{a}$

\begin{tabular}{|l|r|lc|}
\hline Model & F & \multicolumn{2}{|c|}{ Sig. } \\
\hline Regression & 7.168 & & $.000^{\mathrm{a}}$ \\
Residual & & & \\
Total & & & \\
\hline
\end{tabular}

Sumber : Data sekunder yang diolah, 2018

Pada tabel 4.6 menunjukkan bahwa angka signifikasi variabel hasil investasi, pendapatan premi dan beban klaim adalah sebesar 0.000. Untuk menentukan pengujian menggunakan tingkat signifikasi 5\% (0.05). Karena angka signifikasinya lebih kecil dari tingkat signifikasinya maka hipotesis yang menyatakan bahwa "terdapat pengaruh hasil investasi, pendapatan premi, dan beban klaim secara simultan terhadap peertumbuhan asset pada asuransi jiwa yang terdaftar di Otoritas Jasa Keuangan” diterima.

\section{Uji Koefisien Determinasi (R)}

Tabel 4.8

Koefisien Determinasi

Model Summaryb

\begin{tabular}{|c|c|c|c|c|}
\hline Model & $\mathrm{R}$ & $\begin{array}{c}\mathrm{R} \\
\text { Square }\end{array}$ & Adjusted R Square & $\begin{array}{c}\text { Std. Error of the } \\
\text { Estimate }\end{array}$ \\
\hline 1 & $.379^{a}$ & .144 & .124 & .97996 \\
\hline
\end{tabular}

Sumber : Data Sekunder yang diolah, 2018

Berdasarkan tabel 4.7 dapat diketahui bahwa nilai Adjusted $\mathrm{R}^{2}$ adalah 0.144. hal ini menunjukkan bahwa pengaruh hasil investasi, pendapatan premi, dan beban klaim secara simultan terhadap pertumbuhan asset pada asuransi jiwa yang terdaftar di Otoritas Jasa Keuangan" sebesar 14\% sedangkan sisanya sebesar $86 \%$ dipengaruhi oleh model lain di luar penelitian ini seperti misalnya rasio likuiditas, beban operasional, permodalan atau yang lainnya.

\section{Kesimpulan dan Saran.}

\section{Kesimpulan}

1. Hasil Investasi selama periode tahun-tahun tersebut mempunyai kontribusi terhadap pertumbuhan asset asuransi dimana ketika hasil investasinya besar maka perusahaan dapat mengalokasikan investasi kedalam pos-pos yang menguntungkan bagi 
perusahaan asuransi jiwa. Dalam hal ini perusahaan harus jeli investasi mana yang menguntungkan dengan tingat resiko yang kecil.

2. Pendapatan Premi memberikan peranan terhadap pertumbuhan aset dimana semakin besar pendapatan premi yang didapat maka pertumbuhan asset mengalami kenaikan, Semakin kecil pendapatan premi maka pertumbuhan asset mengalami penurunan. Perusahaan harus dapat menghasilkan premi yang nantinya dapat menutupi biaya klaim, perusahaan harus bisa mengestimasi biaya klaim dimasa yang akan datang sehingga tidak terjadi kerugian untuk perusahaan.

3. Hubungan klaim dengan pertumbuhan asset berbanding terbalik, hal ini sesuai dengan konsep beban bahwa beban mewakilkan kenaikan kewajiban atau penurunan asset, dan mempengaruhi ekuitas. Dalam penelitian ini klaim memberikan hasil yang negatif sehingga berpengaruh terhadap pertumbuhan aset asuransi. Perusahaan dapat mengkondisikan beban klaim yang terjadi sehingga tidak menimbulkan dampak buruk bagi asuransi.

4. Hasil Investasi, Pendapatan Premi dan Beban Klaim mempunyai peranan yang penting dalam pertumbuhan aset asuransi. Keuntungan ketika perusahaaan dapat mengontrol siklus dari ketiga variabel tersebut adalah dengan sendirinya perusahaan mampu memberikan posisi aset yang baik..

\section{Saran}

1. Dalam hal investasi sebaiknya perusahaan lebih memaksimalkan dana untuk pos - pos investasi yang lebih menguntungkan supaya dalam pencapaian tingkat pertumbuhan asset sesuai yang diharapkan.

2. Dapat menambahkan variabel independen lain atau indikator yang lain yang diperkirakan dapat mempengaruhi variabel pertumbuhan asset seperti menambahkan biaya operasional, permodalan, likuiditas dan lainnya untuk penelitian selanjutnya.

3. Dapat menambahkan periode tahun dalam pengambilan sampel penelitian supaya dapat dibandingkan.

\section{Daftar Pustaka}

Ghozali, I. (2013). Aplikasi Analisis Multivariate Dengan SPSS. Semarang: Badan Penerbit Universitas Diponegoro.

H. Asep Ramdan Hidayat, M. I. (2015). Pengaruh Premi dan Klaim Terhadap Pertumbuhan Aset pada PT. Sinarmas Asuransi Syari'ah tahun 2013 - 2015. .Prosiding keuangan dan perbankan syariah Vol 01, No. 02, Agustus 2015., 363-372.

Hidayat, M. (2012). Manajemen Aset (Privat dan Publik). Yogyakarta: Laksbang Pressindo.

Imanda, P. (2017). Pengaruh Klaim, Premi, Hasil Investasi, dan Beban Operasional Terhadap Pertumbuhan Aset Asuransi Kerugian Syariah di Indonesia". . Skripsi UIN Raden Fatah Palembang, 50-100.

Indrawan, P. R. (2017). Metodologi Penelitian. Bandung : PT.Refika Aditama. 
Istianingsih Sastrodiharjo, I. P. (2015). Faktor-Faktor Yang Mempengaruhi Pertumbuhan Aset Perusahaan Asuransi Jiwa Non Syariah di Indonesia. Jurnal Akuntabilitas Vol. VIII, No. 01, April 2015, 18-38.

Jiwasraya. (2016, Februari 03). Kinerja tahun 2015 pertumbuhan asuransi jiwa mepet. Retrieved Oktober 07, 2018, from www.jiwasraya.co.id: https://www.jiwasraya.co.id/id/berita/berita-asuransi/kinerja-tahun-2015pertumbuhan-aset-asuransi-jiwa-mepet

Jogiyanto, H. (2010). Teori Portofolio dan Analisis Investasi. Yogyakarta: BPFE.

John Wild, S. (2010). Analisis Laporan Keuangan . Jakarta: Salemba Empat.

Keuangan, O. J. (2016, Januari 26). Daftar-Perusahaan-Asuransi-Umum-Jiwa-ReasurasniAsuransi-Wajib-dan-Asuransi-Sosial.aspx. Retrieved Mei 06, 2018, from www.ojk.go.id:https://www.ojk.go.id/kanal/IKBN/Beritadankegiatan/Publikasi/Pages/ Daftar-Perusahaan-Asuransi-Umum-Jiwa-Reasurasni-Asuransi-Wajib-dan-AsuransiSosial.aspx.

Martono, A. (2013). Manajemen Keuangan. Yogyakarta: Ekonisia.

Purnomo, A. (2017). Analisis Pembayaran Premi Dalam Asuransi Syariah. Journal of Islamic Economics.Volume 1 Nomor 1, Januari 2017, 27-40.

Salim, A. (2012). Asuransi dan manajemen risiko. Jakarta: Rajawali Pres.

Sugiyono. (2013). Metode Penelitian. Bandung: Alfabeta.

Sunariyah. (2010). Pengantar Pengertahuan Pasar Modal. Yogyakarta: UPP AMP YKPN.

Sunyotor, D. W. (2017). Manajemen Risiko dan Asuransi. Yogyakarta: CAPS.

Supranto, J. (2016). Statistik Teori Dan Aplikasi. Jakarta: Erlangga.

Ulandari, A. (2017). UPengaruh Premi Dan Dana Tabarru' Terhadap Pertumbuhan Aset Perusahaan Asuransi Umum Syariah Di Indonesia Tahun 2012-2015. Skripsi Institut Agama Islam Negeri Surakarta, 66., 1-82.

Winarso, W. (2014). Analisa Biaya Klaim Nasabah Terhadap Laba Perusahaan Asuransi. Moneter, Vol. I No. 1 April 2014, 79-86. 